\title{
Comparative Modulatory Assessment of the Sperm Quality and Testicular Function by Solvent Fractions of the Cannabis Extract in Rats
}

\author{
Nwonuma Charles O', ${ }^{1,}$, Favours God'slove Oluwafemi', Rotimi Damilare E', Alejolowo Omokolade O', Ojo \\ Oluwafemi A' ${ }^{1}$, Afolabi Boluwatife $L^{1}$, Irokanulo Emenike $\mathbf{O}^{2}$
}

Nwonuma Charles $\mathrm{O}^{1, *}$, Favours

God'slove Oluwafemi', Rotimi

Damilare $E^{1}$, Alejolowo Omokolade

O', Ojo Oluwafemi A', Afolabi

Boluwatife L'1, Irokanulo Emenike $\mathrm{O}^{2}$

'Department of Biochemistry, College of Pure and Applied Sciences Landmark University,

Omuaran, NIGERIA

${ }^{2}$ Department of Microbiology College of Pure and Applied Sciences Landmark University,

Omuaran, NIGERIA.

\section{Correspondence}

\section{Nwonuma Charles $\mathbf{O}$}

Department of Biochemistry, College of

Pure and Applied Sciences Landmark

University, Omuaran, NIGERIA.

E-mail: nwonuma.charles@Imu.edu.ng

History

- Submission Date: 21-01-2021;

- Review completed: 19-03-2021;

- Accepted Date: 25-10-2021.

DOI : 10.5530/pj.2021.13.216

Article Available online

http://www.phcogj.com/v13/i6

Copyright

(c) 2021 Phcogi.Com. This is an openaccess article distributed under the terms of the Creative Commons Attribution 4.0 International license.

\begin{abstract}
Background: The bioactive ingredients present in medicinal plants have various pharmacological activities which have explored for therapeutic and management of disease conditions like infertility. Objective: This study evaluated the comparative modulations on semen quality and testicular function in the rat by solvents soluble portions of ethanolic leaf extract in varying polar solvents. Methods: Thirty Wistar rats were randomly placed into five groups (A, B, C, D, E and F) with five rats per group: A, control: $0.2 \mathrm{ml} 2 \%$ DMSO was administered, B (vitamin C): $90 \mathrm{mg} / \mathrm{kg}$ body weight, $4.4 \mathrm{mg} / \mathrm{kg}$ body weight of $\mathrm{n}$-hexane, 3.65 $\mathrm{mg} / \mathrm{kg}$ body weight of ethyl acetate, $0.52 \mathrm{mg} / \mathrm{kg}$ body weight of $\mathrm{n}$-butanol and $0.18 \mathrm{mg} / \mathrm{kg}$ body weight of the residual portion of Cannabis leaf extract were given to groups C, D, E and F, respectively. The rats were sacrificed 24 hours after the last day of 60 days of treatment. Results: Sperm indices, testosterone, $\mathrm{FSH}$, LH, and HDL showed significant increase $(\mathrm{p} \leq 0.05)$ across the treatment groups compared to normal control. Similarly, there was a significant increase in activity $(p \leq 0.05)$ of ALP, ACP, SOD, and CAT across the treatment groups compared to normal control. In addition, there were significant increases in GSH, MDA, triglyceride, cholesterol, total protein concentration levels across the treatment groups compared to normal control. The n-butanol soluble portion showed normal histomorphology with typica seminiferous tubule with spermatogonia lying on the basement membrane. Conclusion: Testicular integrity and improved sperm quality were pronounced in rats administered $\mathrm{n}$-butanol solvent portion.

Key words: Cannabis, Sperm, Fertility, Testis, Medicinal.
\end{abstract}

\section{INTRODUCTION}

In the current situation, approximately 8-12 per cent of individuals globally suffer from infertility ${ }^{1}$. Male infertility is mainly due to Hormonal imbalance and low sperm quality. Over 90 percent of male infertility issues are associated with low sperm levels ${ }^{2}$. The testis is prone to the use of harmful substances that may interfere with spermatogenesis, resulting in a decline in the quality of semen required for fertility ${ }^{3}$. Herbal treatments due to the abundant antioxidant phytochemical present in medicinal plants are currently being investigated as an effective option for infertile conditions in humans. Cannabis, an annual herbaceous plant of the genus cannabis, a cannabinaceae species, has been identified by researchers as a biologically active weed that can be pharmacologically potent for human fertility ${ }^{4}$. Cannabis was used experimentally to treat some disease conditions, including dementia, multiple sclerosis, Parkinson's disease, social anxiety disorder, depression, disorder, and neuropathic pain, etc., and some degree of efficacy was reported ${ }^{5}$. However, given its increasing prevalence in the medical and recreational sectors, substantial research is required to explain the potential negative and positive effects of marijuana. Changes in reproductive hormones, impaired semen requirements and decreased libido and sexual function have been associated with the use of cannabis, particularly in the field of male fertility ${ }^{6}$.
The comparative potential of solvent portions of cannabis leaf extract for modulating testicular function and sperm quality in Wistar rats was therefore explored in this study.

\section{MATERIALS AND METHODS}

Procurement of Cannabis and Preparation of solvents portions of the extract

Dry cannabis leaves were obtained from the Ilorin National Drug Law Enforcement Agency (N.D.L.E.A). $20 \mathrm{~g}$ ethanolic leaf extract of cannabis was weighed and dissolved in $500 \mathrm{ml}$ of a mixture of $n$-hexane and water $(1 / 1 \mathrm{v} / \mathrm{v})$ and left in an orbital shaker for homogenization. The mixture was placed and left overnight in a separate funnel. The $n$-hexane soluble portion was collected and kept, and then the remaining insoluble portion was added to the mixture of equivalent amounts of ethyl acetate and water $(\mathrm{v} / \mathrm{v})$. With the separating funnel, the homogeneous mixture produced was separated. A mixture of equivalent amounts of $\mathrm{n}$-butanol and water was added to the remaining portion when the ethyl acetate soluble portion was extracted. The homogeneous mixture was separated with separating funnel. The n-butanol portion was gradually removed and the left water portion was stored as a residual portion. The extracted portions were separately concentrated using the rotary evaporator. Subsequently, they were dried at $40{ }^{\circ} \mathrm{C}$ in a water bath 


\section{Chemicals and reagents used}

The entire chemical used in this experiment was of analytical grade and were prepared according to the standard methods, and it consists of volumetric flask, measuring cylinder, distilled water, and reagents bottles. The reagents prepared were stored in air tight bottles at room temperature, while some were refrigerated.

\section{Animal procurement and Experimental Design}

Thirty Wistar rats weighing between $120-140 \mathrm{~g}$ were procured from the animal house of Department of Biochemistry, University of Ilorin. The rats were put in metal cages and were placed a well-ventilated space in the animal house of Landmark University and were allowed to acclimatize for seven days before the experiment commenced. The animals were allowed access to their feed and water ad libitium. Thirty Wistar rats were randomly placed into five groups (A, B, C, D, E and F) with five rats per group:

Group A (control): Rat were orally administered $0.2 \mathrm{ml} 2 \%$ DMSO for 60 days

Group B (vitamin C): Rats were orally administered $90 \mathrm{mg} / \mathrm{kg}$ body weight of vitamin $\mathrm{C}$ for 60 days

Group C: Rats were orally administered $4.4 \mathrm{mg} / \mathrm{kg}$ body weight of $\mathrm{n}$-hexane portion of cannabis extract leaf extract for 60 days.

Group D: Rats were orally administered $3.65 \mathrm{mg} / \mathrm{kg}$ body weight of ethyl acetate portion of cannabis leaf extract for 60 days

Group E: Rats were orally administered $0.52 \mathrm{mg} / \mathrm{kg}$ body weight of n-butanol portion of cannabis leaf extract for 60 days

Group F: Rats were orally administered $0.18 \mathrm{mg} / \mathrm{kg}$ body weight of the residual portion of cannabis leaf extract for 60 days.

\section{Animal sacrifice and Collection of the animal tissues}

Following the experimental protocols for the handling of animals ${ }^{7}$, the animals in this study were sacrificed 24 hours after the last day of the 60 -day experiment. The rats were anaesthetized with diethyl ether and the jugular vein was then cut open to pump the blood into the sterilized sample container. Blood samples were further centrifuged at $5000 \mathrm{rpm}$ for 5 minutes using a refrigerated centrifuge to separate serum. The serum collected was transferred to fresh sterile sample bottles and placed in the freezer before biochemical tests. The testes were taken from rats, homogenized, frozen and used for biochemical assays. A small portion of the tissue from the representative testes was cut and put in $10 \%$ of the formal saline solution for histological examination.

\section{Preparation of organs for biochemical analysis}

The testicular tissue was homogenized in an appropriate buffer for an assay. The homogenate was further centrifuged at $5000 \mathrm{x} \mathrm{g}$ for 10 minutes. The supernatants were used for the assay.

\section{Biochemical assays}

Glycogen concentration was estimated by the method described by Kemp et al. ${ }^{8}$ while Nitric oxide (NO) concentration was evaluated by the procedure described by Ilavarasan et al ${ }^{9}$. Rao and Ramakrishnan ${ }^{10}$ described the method for the evaluation of 3-hydroxy-3-methylglutarylCoA reductase activity in testis by measuring the ratio of 3-hydroxy-3 -methylglutaryl-CoA and mevalonate concentrations. Superoxide dismutase (SOD) was measured by the method described by Misra and Fridovich $^{11}$. The GSH level in the testis was estimated according to the procedure described by Jollow et al $^{12}$. Catalase activity in the testis was measured according to the method described by $\mathrm{Aebi}^{13}$. The principle of reaction between MDA and thiobarbituric acid (TBA) under acidic condition was described by Satoh ${ }^{14}$ for the Malondialdehyde (MDA) assay. The total protein concentration estimated by the method described by Gornall et al. ${ }^{15}$. The methods described by Wright et al ${ }_{16,17}(1972 \mathrm{a} \& \mathrm{~b})$ were used to estimate the activities of ACP and ALP. The LH FSH and testosterone were quantified in the serum on the procedure based on a solid phase enzyme-linked immunosorbent assay (ELISA).

\section{Tissue lipid extraction and estimation of concentration}

Lipids in the freshly harvested testis were extracted following the method described by Folch et al. ${ }^{18}$. Finally, the content of cholesterol and triglyceride were quantified spectrophotometrically using the kit. High-density lipoprotein (HDL-c) of the plasma was determined through the precipitation method using kit.

\section{Histopathology}

The testes were extracted and immediately fixed in $10 \%$ of the formalsaline solution for histopathological analysis. The tissue samples were embedded in paraffin and then cut into a cross-section of 4-5 mm thickness and stained with hematoxylin-eosin. Histological sections were analyzed and photographed by Olympus BX50 (Japan) photomicroscope.

\section{Data Analysis}

The data were expressed as the mean of three \pm SEM determinations; one-way variance analysis (ANOVA) followed by post hoc Tukey to compare mean and assess significant differences between variables at $\mathrm{p} \leq 0.05$ between the variables. All statistical analyses were carried out using the Social Science Statistical Package, version 22 (SPSS Inc. Illinois, Chicago, USA).

\section{RESULTS}

There was an increase in the percentage weight change in the entire treatment group compared to the normal control (table 1). The increase in the sperm volume was not significant, contrary there was a significant increase in the following parameters of sperm: concentration count, motile count, total count and $\%$ motility in the rat treated with vitamins $\mathrm{C}$ and different solvents soluble portion the extract respectively (table 2). Similarly, for the progressive assessment, there was a significant increase in the numbers of fast sperms in the treated groups compared to the normal control, contrary the groups administered n-hexane, ethyl acetate, $n$-butanol and vitamin $C$ showed a significant decrease in the slow sperm cells compared to the normal control (table 3). There was a significant increase in the number of normal sperm in the treated groups compared to the normal control (table 4). Also, there was a significant decrease in sperms with tail defect neck defect and head defect in the treated groups compared to the normal group (table 4). There was a significant increase in the serum levels of LH in rats in the treated groups compared to normal control (figure 1A). Similarly, the rats treated with $\mathrm{n}$-hexane, ethyl acetate and n-butanol solvent portions respectively showed a significant increase in serum level of FSH compared to normal control (figure 1B). There was a significant increase in the testosterone serum level in the rats treated with $\mathrm{n}$-butanol solvent portion and a significant decrease in levels in the groups administered $\mathrm{n}$-hexane, ethyl acetate and the residual portion of cannabis extract (figure 1C). There was a significant decrease in the HMG-CoA/ mevalonate ratio in the testis of the $n$-hexane and $n$-butanol portions of the cannabis extract, respectively. There was also a substantial increase in the HMG-CoA/mevalonate ratio in rats administered vitamin $\mathrm{C}$, the ethyl acetate portion of the extract and the residual portion of the extract relative to standard control (figure $2 \mathrm{~A}$ ). The concentration of testicular cholesterol showed a significant increase $(p \leq 0.05)$ in the groups administered ethyl acetate and n-butanol portion of the 
Table 1: Percentage weight change of testis of rats treated with solvents soluble portions of ethanolic leaf extract of cannabis for 60 days.

\begin{tabular}{lccc}
\hline Group & Initial weight & Final weight & \% Weight change \\
\hline Normal control & $212.62 \pm 13.62$ & $218.13 \pm 9.81$ & $8.03 \pm 3.05$ \\
$\mathbf{9 0} \mathbf{~ m g / k g ~ B W ~ V i t a m i n ~ C ~}$ & $211.00 \pm 9.86$ & $237.49 \pm 11.17$ & $18.64 \pm 5.99$ \\
$\mathbf{4 . 4} \mathbf{~ m g / k g ~ B W ~ ( n - h e x a n e ) ~}$ & $187.33 \pm 8.41$ & $217.71 \pm 5.20$ & $5.32 \pm 2.14$ \\
$\mathbf{3 . 6 5} \mathbf{~ m g / k g ~ B W ~ ( e t h y l ~ a c e t a t e ) ~}$ & $190.33 \pm 12.99$ & $219.97 \pm 13.10$ & $12.27 \pm 5.19$ \\
$\mathbf{0 . 5 2} \mathbf{~ m g / k g ~ B W ~ ( n - b u t a n o l ) ~}$ & $203.00 \pm 3.00$ & $238.95 \pm 14.09$ & $15.26 \pm 6.03$ \\
$\mathbf{0 . 1 8} \mathbf{~ m g / k g ~ B W ~ ( r e s i d u a l ) ~}$ & $198.33 \pm 6.35$ & $228.10 \pm 3.91$ & $18.20 \pm 4.83$
\end{tabular}

Table 2: Sperm parameters of rats treated with solvents soluble portions of ethanolic leaf extract of cannabis for 60 days.

\begin{tabular}{|c|c|c|c|c|c|}
\hline Group/Parameter & Sperm volume $(\mathrm{mL})$ & $\begin{array}{l}\text { Concentration count } \\
\qquad\left(\times 10^{6} \mathrm{~mL}\right)\end{array}$ & $\begin{array}{l}\text { Motile count } \\
\qquad\left(10^{6} \mathrm{~mL}\right)\end{array}$ & $\begin{array}{l}\text { Total count } \\
\left(\times 10^{6} \mathrm{~mL}\right)\end{array}$ & Motility (\%) \\
\hline Normal control & $1.59 \pm 0.08^{\mathrm{a}}$ & $133.33 \pm 6.67^{\mathrm{a}}$ & $56.67 \pm 3.33^{\mathrm{a}}$ & $193.33 \pm 9.28^{\mathrm{a}}$ & $50.00 \pm 0.00^{\mathrm{a}}$ \\
\hline $90 \mathrm{mg} / \mathrm{kg}$ BW Vitamin C & $1.71 \pm 0.01^{\mathrm{a}}$ & $293.33 \pm 6.67^{\mathrm{b}}$ & $246.67 \pm 3.33^{\mathrm{b}}$ & $504.33 \pm 8.67^{\mathrm{b}}$ & $85.00 \pm 1.00^{c}$ \\
\hline $4.4 \mathrm{mg} / \mathrm{kg}$ BW (n-hexane) & $1.60 \pm 0.00^{\mathrm{a}}$ & $150.00 \pm 11.55^{\mathrm{bc}}$ & $96.67 \pm 3.33^{\mathrm{ac}}$ & $278.00 \pm 2.00 \mathrm{a}^{\mathrm{b}}$ & $65.00 \pm 3.33^{\mathrm{b}}$ \\
\hline $3.65 \mathrm{mg} / \mathrm{kg}$ BW (ethyl acetate) & $1.71 \pm 0.07^{\mathrm{a}}$ & $220.00 \pm 17.32^{\mathrm{d}}$ & $180.00 \pm 20.00^{c}$ & $440.00 \pm 10.00^{c}$ & $78.00 \pm 2.00^{c}$ \\
\hline $0.52 \mathrm{mg} / \mathrm{kg}$ BW (n-butanol) & $1.69 \pm 0.02^{\mathrm{a}}$ & $230.00 \pm 10.00^{\mathrm{d}}$ & $193.33 \pm 6.67^{\mathrm{d}}$ & $397.00 \pm 11.36^{\mathrm{aa}}$ & $80.67 \pm 6.67^{c}$ \\
\hline 0.18 mg/kg BW (residual) & $1.63 \pm 0.02^{\mathrm{a}}$ & $186.67 \pm 13.33^{\mathrm{c}}$ & $143.33 \pm 6.67 \mathrm{ad}$ & $322.00 \pm 12.00^{\mathrm{d}}$ & $70.72 \pm 3.12^{b}$ \\
\hline
\end{tabular}

The values are expressed as means of three replicates \pm SEM. One way ANOVA was followed by Tukey's multiple comparison: abcd P $\leq 0.05$ significance differences compared with the normal control.

Table 3: Sperm progressive assessment of rats treated with solvents soluble portions of ethanolic leaf extract of cannabis for 60 days.

\begin{tabular}{|c|c|c|}
\hline Group & fast & slow \\
\hline Normal control & $51.67 \pm 3.33^{\mathrm{a}}$ & $50.00 \pm 2.88^{c}$ \\
\hline $90 \mathrm{mg} / \mathrm{kg}$ BW Vitamin C & $83.33 \pm 0.88^{c}$ & $17.67 \pm 1.45^{\mathrm{a}}$ \\
\hline $4.4 \mathrm{mg} / \mathrm{kg} \mathrm{BW}$ (n-hexane) & $64.33 \pm 2.33^{\mathrm{b}}$ & $37.33 \pm 2.67^{\mathrm{b}}$ \\
\hline $3.65 \mathrm{mg} / \mathrm{kg} \mathrm{BW}$ (ethyl acetate) & $81.67 \pm 1.67^{c}$ & $17.67 \pm 1.45^{\mathrm{a}}$ \\
\hline $0.52 \mathrm{mg} / \mathrm{kg}$ BW (n-butanol) & $81.67 \pm 1.67^{\mathrm{c}}$ & $16.00 \pm 1.00^{\mathrm{a}}$ \\
\hline $0.18 \mathrm{mg} / \mathrm{kg} \mathrm{BW}$ (residual) & $68.00 \pm 6.00^{\mathrm{b}}$ & $31.78 \pm 3.78^{\mathrm{d}}$ \\
\hline
\end{tabular}

The values are expressed as means of three replicates \pm SEM. One way ANOVA was followed by Tukey's multiple comparison: abcd $\mathrm{P} \leq 0.05$ significance differences compared with the normal control.

Table 4: Sperm morphology of rats treated with solvents soluble portions of ethanolic leaf extract of cannabis for 60 days.

\begin{tabular}{|c|c|c|c|c|}
\hline Group & normal & Tail defect & Neck defect & Head defect \\
\hline Normal control & $51.00 \pm 2.08^{\mathrm{a}}$ & $22.67 \pm 1.45^{\mathrm{c}}$ & $11.00 \pm 0.57^{c}$ & $13.00 \pm 2.08^{b}$ \\
\hline $90 \mathrm{mg} / \mathrm{kg}$ BW Vitamin C & $82.00 \pm 2.00^{c}$ & $8.00 \pm 0.57^{\mathrm{a}}$ & $4.33 \pm 0.33^{\mathrm{a}}$ & $5.00 \pm 1.73^{\mathrm{a}}$ \\
\hline $4.4 \mathrm{mg} / \mathrm{kg}$ BW (n-hexane) & $64.33 \pm 2.33^{\mathrm{b}}$ & $21.33 \pm 1.33^{c}$ & $8.33 \pm 0.88^{c}$ & $5.67 \pm 0.33^{\mathrm{a}}$ \\
\hline 3.65 mg/kg BW (ethyl acetate) & $80.00 \pm 2.88^{c}$ & $8.67 \pm 0.67^{\mathrm{a}}$ & $7.00 \pm 1.00^{\mathrm{b}}$ & $5.33 \pm 0.88^{\mathrm{a}}$ \\
\hline $0.52 \mathrm{mg} / \mathrm{kg}$ BW (n-butanol) & $81.00 \pm 1.00^{c}$ & $8.00 \pm 0.57^{\mathrm{a}}$ & $5.33 \pm 0.33^{\mathrm{b}}$ & $5.0 \pm 0.57^{\mathrm{a}}$ \\
\hline $0.18 \mathrm{mg} / \mathrm{kg}$ BW (residual) & $72.67 \pm 1.45^{\mathrm{b}}$ & $13.33 \pm 1.33^{\mathrm{b}}$ & $7.67 \pm 0.33^{b}$ & $9.67 \pm 0.88^{b}$ \\
\hline
\end{tabular}

The values are expressed as means of three replicates \pm SEM. One way ANOVA was followed by Tukey's multiple comparison: abcd $P \leq 0.05$ significance differences compared with the normal control.

cannabis extract, while the groups administered vitamin $\mathrm{C}$, n-hexane and residual portion respectively showed a significant decrease in the concentration of testicular cholesterol (figure 2B). N-butanol and ethyl acetate solvent portion of cannabis leaf extract increased the concentration of testicular triglyceride significantly compared to normal control (Figure 2C), while vitamin $\mathrm{C}$ and $\mathrm{n}$-hexane soluble portion of the extract significantly decreased testicular triglyceride. Also, the serum HDL concentration in rats administered soluble solvent portions decreased significantly compared to normal control but was significantly increased in the group administered vitamin $C$ (figure 2D). There was a significant decrease in the organ-body ratio of testis in all the treated groups compared to the normal control (figure $3 \mathrm{~A}$ ). The rats treated with vitamin $C$, ethyl acetate portion, n-butanol portion and the residual portion of the extract showed a significant increase in the testicular total protein concentration compared to the normal control (figure $3 \mathrm{~B}$ ). Contrary, the ALP and ACP activity respectively in the testis of the treated groups significantly decreased compared to the normal control (figure $3 \mathrm{C} \& \mathrm{D}$ ). There SOD activity was not affected in the testis of rats treated vitamin $\mathrm{C}$, n-butanol portion and the residual portion of cannabis extract compared with normal control whereas the activity of the enzyme was significantly increased in the testis of rats treated with n-hexane portion and ethyl acetate portion of cannabis extract (figure 4A). Similarly, there was an increase in the activity of catalase in the testis of the rats in the treated groups except the group treated with the n-butanol portion of the extract which was not affected compared to the normal control (figure 4B). The level of the reduced glutathione in the rats decreased significantly across the treated groups compared with normal control (figure 4C). The MDA level in the testis of rats in the treated groups showed a significant increase compared to the normal control (figure 5D). Rats treated with n-hexane portion and n-butanol portion respectively increased the serum glycogen concentration significantly compared to normal control (figure $5 \mathrm{~A}$ ). The concentration of serum glycogen in rats treated with vitamin $\mathrm{C}$, the portion of ethyl acetate and the residual portion was not affected compared to normal. Similarly, there was a significant increase across the treated groups compared to the normal control 

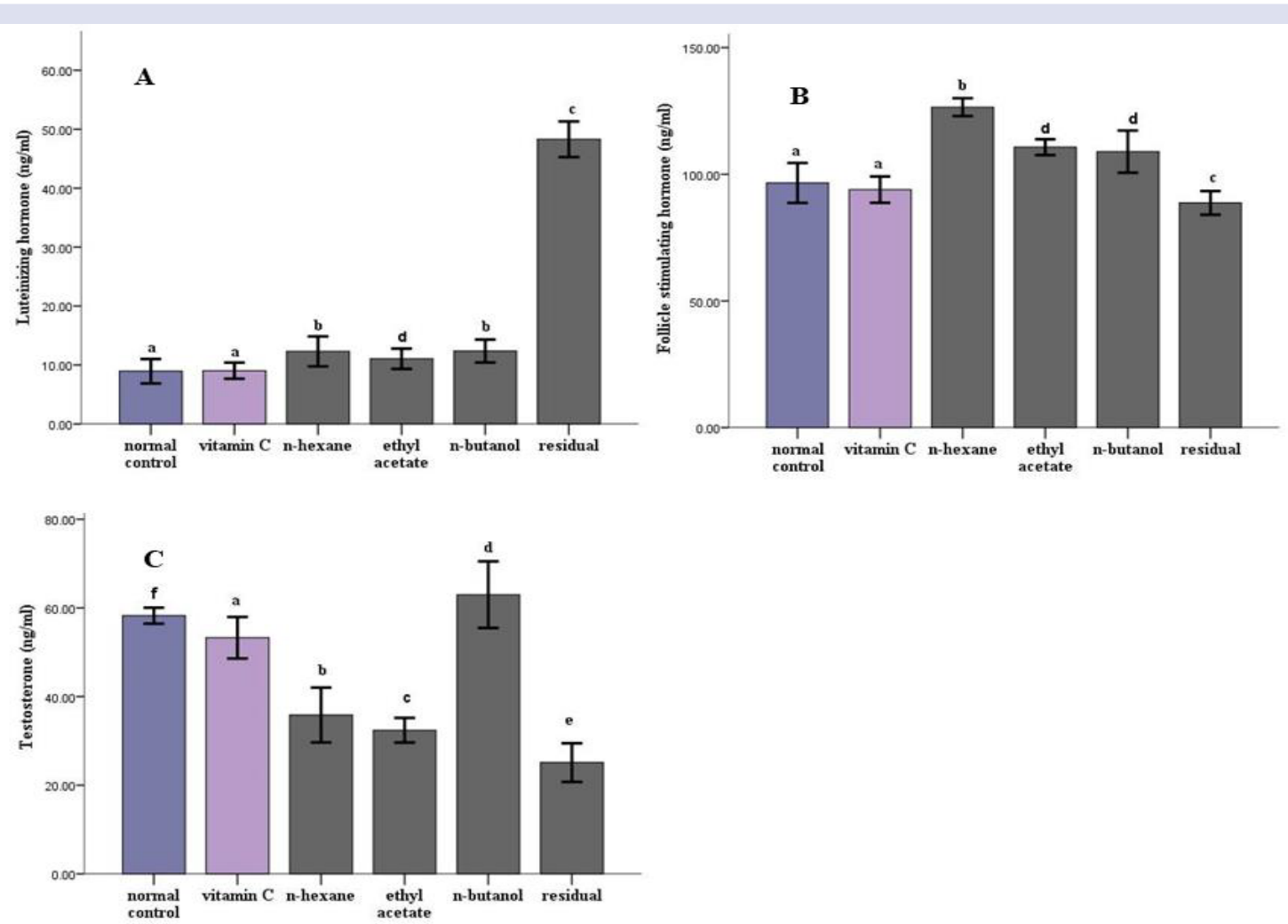

Figure 1: Serum levels of luteinizing hormone (A), follicle stimulating hormone (B), and testosterone (C) in rats treated with soluble portions of ethanolic leaf extract of cannabis for 60 days. The values are expressed as means of three replicates \pm SEM. One way ANOVA was followed by Tukey's multiple comparison: abcd $\mathrm{P} \leq 0.05$ : significance differences compared with the normal control.

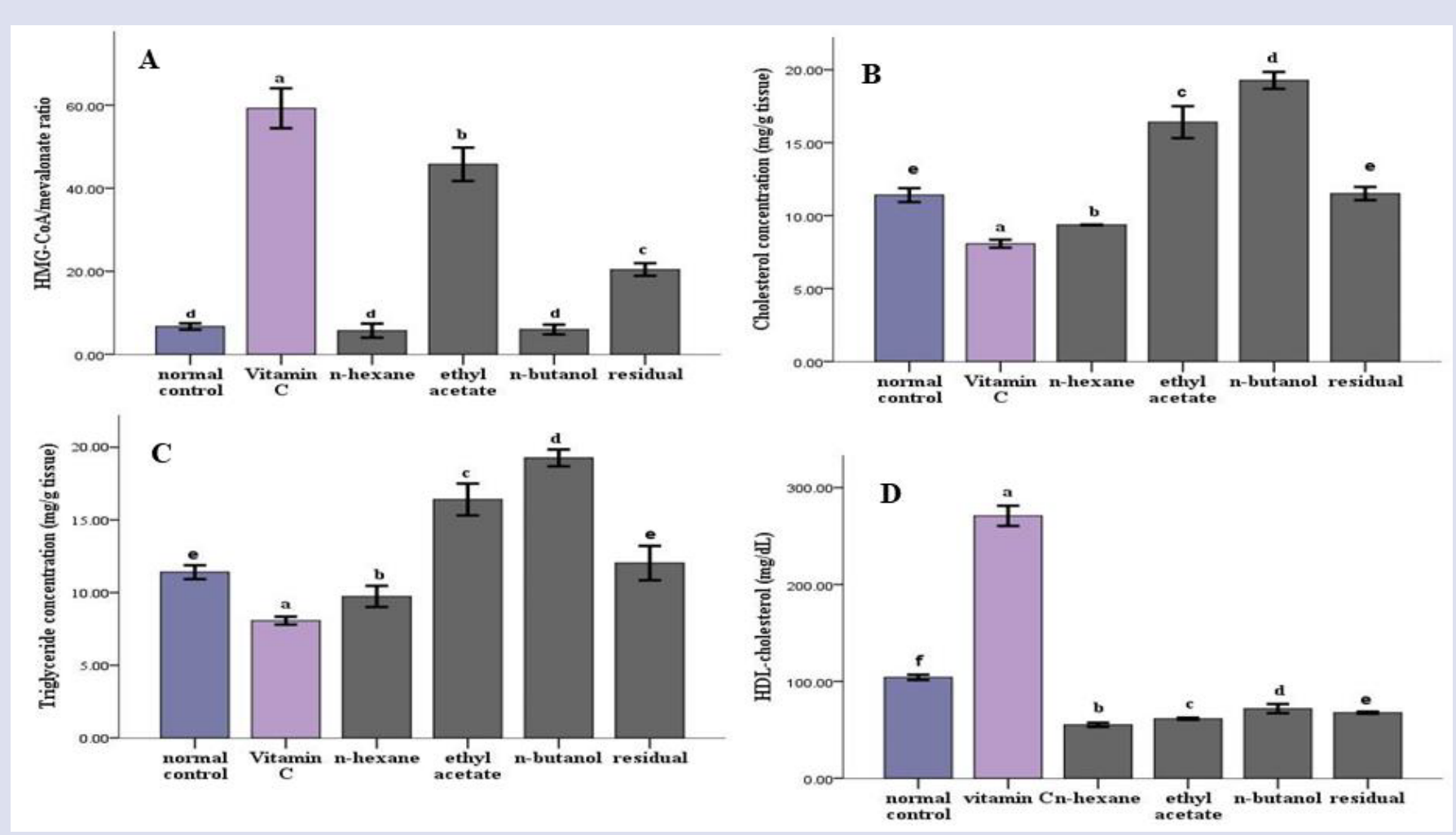

Figure 2: Testicular: HMG-CoA/Mevalonate ratio (A), cholesterol concentration (B), triglyceride concentration (C) and serum HDL concentration (D) in rats treated with soluble portions of ethanolic leaf extract of Cannabis for 60 days. The values are expressed as means of three replicates \pm SEM. One way ANOVA was followed by Tukey's multiple comparison: abcd $\mathrm{P} \leq 0.05$ : significance differences compared with the normal control. 

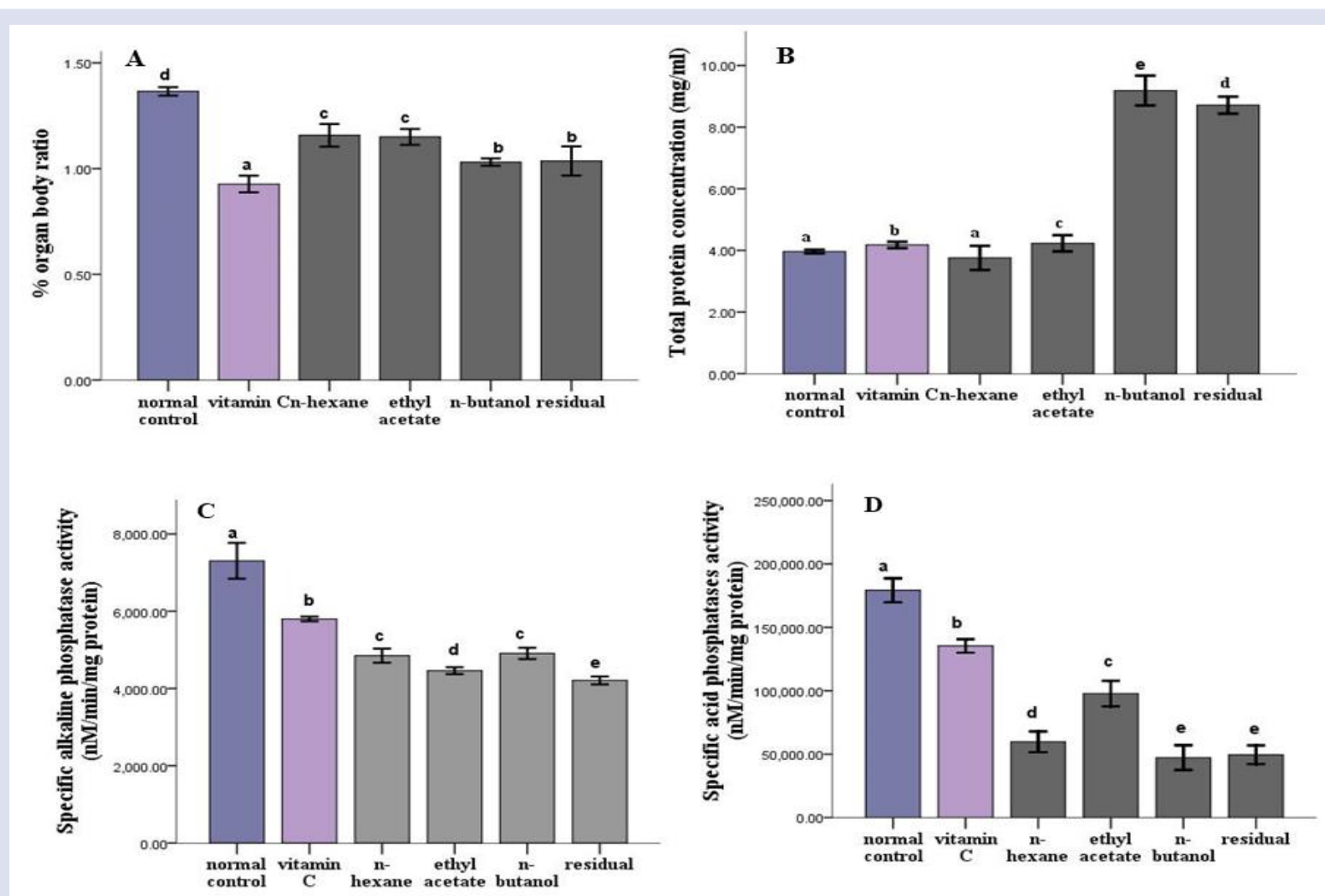

Figure 3: Testicular: organ body weights ratio (A), total protein concentration (B), specific acid phosphatase activity (C) and alkaline phosphatase activity (D) in rats treated with solvents portions of ethanolic leaf extract of Cannabis for 60 days. The values are expressed as means of three replicates \pm SEM. One way ANOVA was followed by Tukey's multiple comparison: abcd $\mathrm{P} \leq 0.05$ : significance differences compared with the normal control.

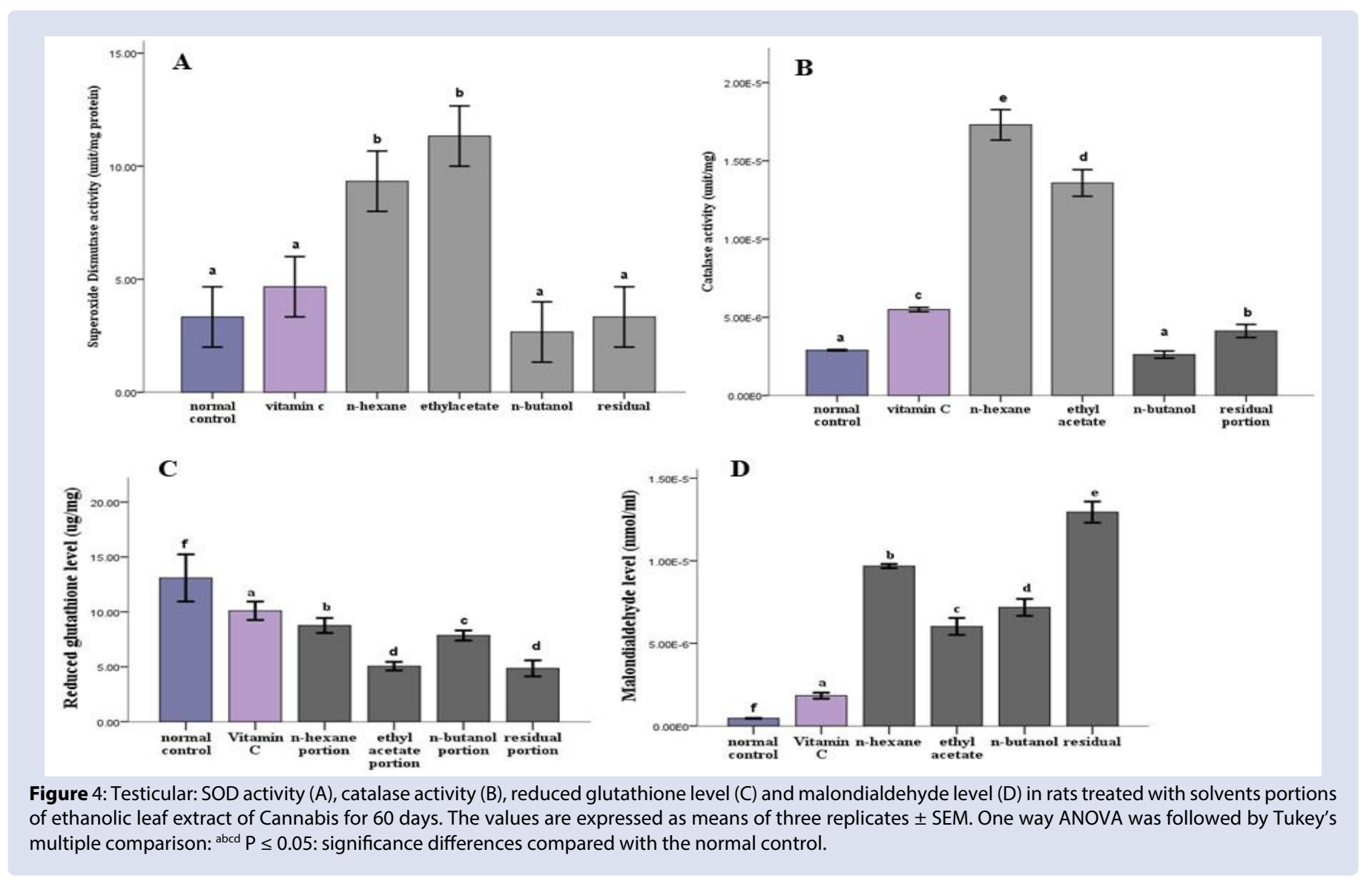




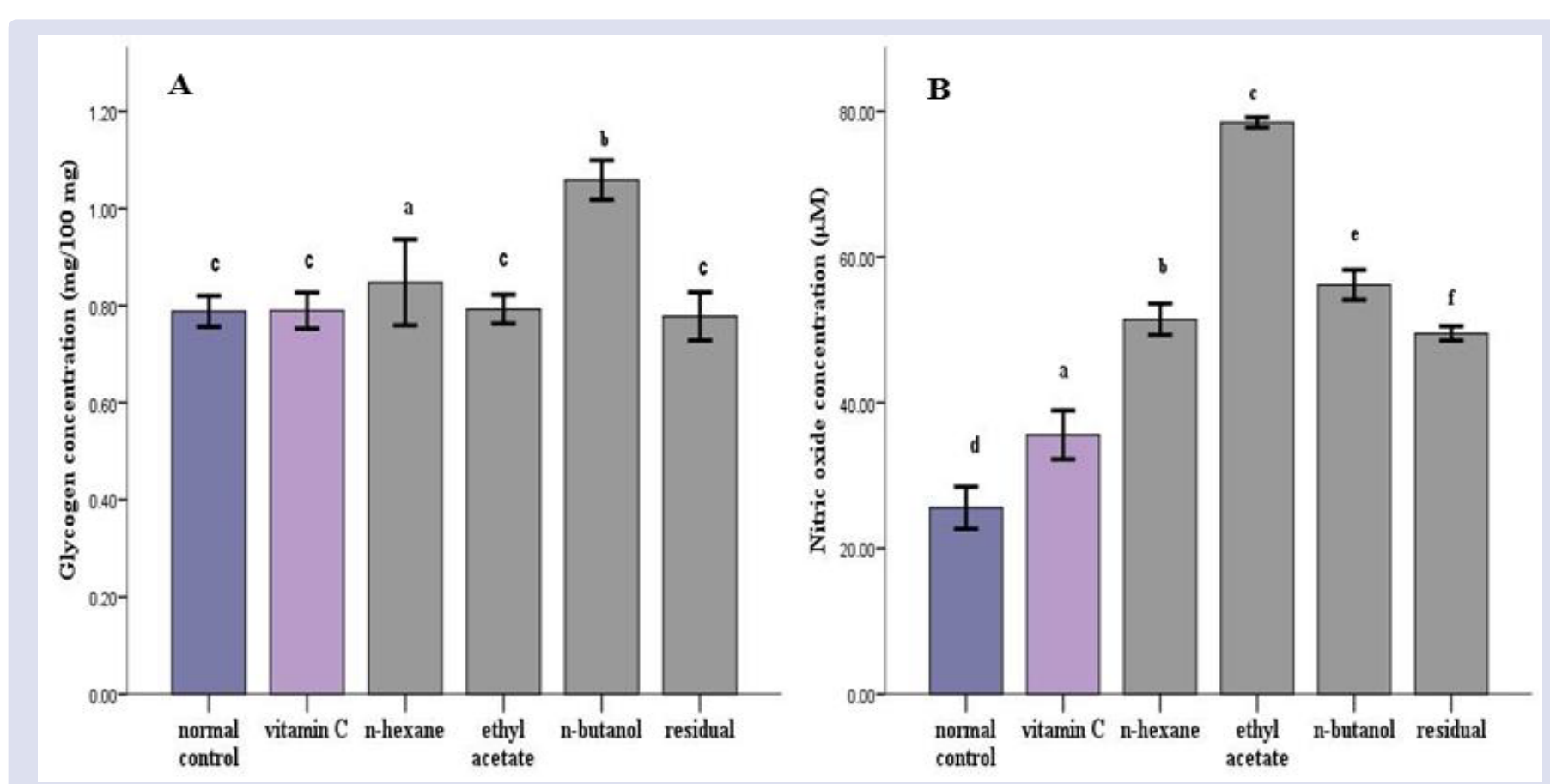

Figure 5: Testicular: glycogen concentration (A) and nitric oxide concentration (B) concentration of rats treated with soluble portions of ethanolic leaf extract of Cannabis for 60 days. The values are expressed as means of three replicates \pm SEM. One way ANOVA was followed by Tukey's multiple comparison: abcd $\mathrm{P} \leq 0.05$ : significance differences compared with the normal control.

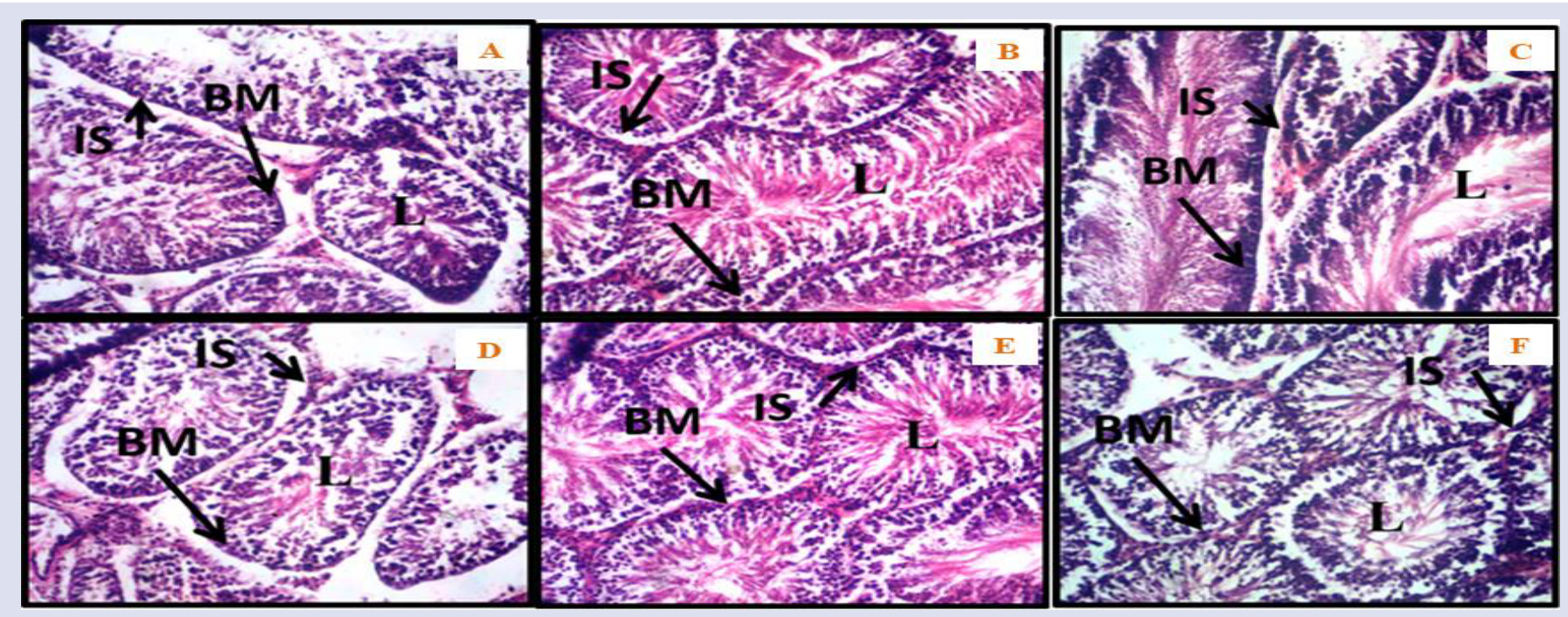

Figure 6: $(\mathrm{H}$ and $\mathrm{E} \mathrm{X100)}$ Photomicrograph of the transverse section of testis experimental animal showing: $\mathbf{A}$ (normal control); degeneration of interstitial cells and increased intracellular spaces of the seminiferous tubules; B (vitamin C); showing normal histomorphology with typical seminiferous tubule containing different types of germ cells; spermatogonia lying on basement membrane with other cells proliferating in a centripetal direction; $\mathbf{C}$ (n-hexane sub-fraction),showing degeneration of interstitial cells and increased intracellular spaces of the seminiferous tubules; D (Ethyl acetate subfraction),showing abnormal widening of interstitial spaces (IS) with degeneration of interstitial cells. Increased intracellular spaces of the seminiferous tubules were also observed; $\mathbf{E}$ ( $\mathbf{n}$-butanol sub-fraction), showing normal histomorphology with typical seminiferous tubule containing different types of germ cells; spermatogonia lying on basement membrane with other cells proliferating in a centripetal direction. No apparent histopathological alteration; $\mathbf{F}$ (residual fraction), showing abnormal widening of interstitial spaces (IS) with degeneration of interstitial cells. (BM: Basement membrane, IS: interstitial space, L: lumen).

(5B). Testis histopathology revealed standard histomorphology with a typical seminiferous tubule containing various forms of germ cells with spermatogonia lying with other cells on the basement membrane (figure 6A).

\section{DISCUSSION}

A healthy testicular function and reproductive hormonal balance are necessary for optimal sperm production. Medicinal plants have been reported to possess multiple bioactive components which can interact with some receptor in the body to trigger a cascade of reactions that will influence the biochemical reactions such as increased hormone production or antioxidant activity. In the process of isolating and further characterization of the target compound, the crude extract was preliminarily concentrated through solvent partitioning. The bioactive components of the cannabis extract were partitioned in this study using solvents with ranging polarities. The portion with the most active modulatory effect may imply a high concentration of the target component. Testicular size is expected to be proportional to the weight 
of the experimental animal which may also be indicative of healthy testis. Testicular cell death: Sertoli, Leydig, and spermatogonia contribute to a decrease in testis weight ${ }^{19}$. The increased percentage of organ weight reported in this study may correlate to intact testicular cells. This may imply a protective effect of the extract which was reported by previous work to be rich in antioxidants. Conversely, the decrease in organ body weight recorded in the experiment was attributed to the disproportion in the weight of the animals within the group. Semen analysis involves descriptive sperm cell and seminal fluid parameter measurements which are indicative of semen quality ${ }^{20}$. Similarly, the quality of semen could be a marker to fertility assessment ${ }^{21}$. The assessed sperm volume, concentration, motile count, total count, per cent motility, progressive sperm assessment, and morphology of sperm were evaluated for sperm quality in this study. The enhanced sperm parameters reported may be suggestive of the effect of the extract on the spermatogenesis process. This altered spermatogenesis may be as a result of modulation of the hormone production process by the extract ${ }^{22}$. The observed increase in the reproductive hormone levels $(\mathrm{LH}$, testosterone and FSH) observed also corroborated the sperm parameters reported. The increase in FSH recorded is reflective of mature and viable sperm cell $^{23}$. Sperm quality in this study is also attributed to the antioxidant activity by the extract. Likewise, previous studies have reported a high flavonoid concentration ${ }^{24,25}$. The reduced level of HMG-CoA/ mevalonate ratio also indicates the activity of HMG-CoA reductase activity, the rate-limiting step in the de-novo cholesterol biosynthesis pathway, the precursor molecule for testosterone synthesis ${ }^{26}$. The consequent increase in cholesterol levels was therefore indicative of the extract's steroidogenic impact. Similarly, the increased amount of triacylglycerides identified as an energy source for spermatogenesis was influenced by this extract ${ }^{27}$. In previous studies, HDL was reported to a source of cholesterol for steroidogenesis ${ }^{28}$, but the decrease in HDL in this study gave credence to testicular de-novo cholesterol synthesis reported in this present study ${ }^{29}$. Testicular protein concentration is responsible for the maturation of spermatozoa ${ }^{30}$. The reported protein concentration increase was indicative of the effect of the extract on the testicular protein synthesis apparatus and this also may be indicative of the sperm quality recorded in this present study. The key source of energy required for the energy-requiring biochemical task of FSH in the Sertoli cells is glycogen storage in the testis ${ }^{31,32}$. The increased concentration of glycogen in the current study also verified the increased level of FSH mentioned earlier. Similarly, the increased NO reported in this study is also reflective of the effect of the extract on testicular function. NO was implicated in the role of spermatogenesis and germ cell degeneration ${ }^{33}$. The increased NO concentration recorded in this study could be due to the extract. Lysosomal enzyme $\mathrm{ACP}$ is a biomarker of spermatogenesis steps mediated by androgenic influence ${ }^{34}$. Likewise, Alp is correlated with plasma membrane permeability and germ cell biomarkers in the cell ${ }^{35}$. The compromised plasma membrane integrity due to lipid peroxidation may have caused leakage of the enzyme resulting in the reduced activity of the enzymes. Also, in this study, the increase in the MDA level was due to oxidative stress occasioned by the long use of the extract ${ }^{36}$. Enzymatic cellular antioxidants that defend against oxidative stress are SOD and catalase. SOD proffers the first line of defence against the oxy-radical deleterious effect on the cell ${ }^{37}$.

In this research, the increase in SOD and catalase activity was indicative of the neutralizing action of the oxidative radicals involved in damage to the membrane. Besides, reduced glutathione is an antioxidant peptide molecule known to protect cells from lipid peroxidation by scavenging superoxide ions and inhibiting oxygen radical formation ${ }^{38}$. The reduced amount of GSH in the testis in this study is also reflective of the antioxidant activity. Histopathological examination of testis revealed normal histomorphology with typical seminiferous tubule containing different types of germ cells. However, the normal histology was reported in the n-butanol fraction, which could be as a result of the antioxidant protective effect of the testicular cells by the extract.

\section{CONCLUSION}

The n-butanol portion of the extract appeared to be the most active in improving the sperm quality and preserve the testicular function reported for the crude extract. The solvent may have precipitated the target compound implicated for the function.

\section{REFERENCES}

1. Sabra SM, Al-Harbi MS. An influential relationship of seminal fluid microbial infections and infertility, Taif Region, KSA. World J Med Sci. 2014; 10:32-7.

2. Kumar N, Singh AK. Trends of male factor infertility, an important cause of infertility: A review of literature. J. Hum. Reprod. Sci. 2015; 8(4):191.

3. Oliveira NN, Félix MA, Pereira TC, Rocha LG, Miranda JR, Zangeronimo MG, Pinto JE, Bertolucci SK, Sousa RV. Sperm Quality and Testicular Histomorphometry of Wistar Rats Supplemented with Extract and Fractions of Fruit of Tribulus terrestris L. Braz Arch Biol Technol. 2015; 58(6):891-7.

4. Payne KS, Mazur DJ, Hotaling JM, Pastuszak AW. Cannabis and male fertility: A systematic review. J Urol. 2019; 202(4):674-81.

5. Shum C, Dutan L, Annuario E, Warre-Cornish K, Taylor SE, Taylor RD, Andreae LC, Buckley NJ, Price J, Bhattacharyya S, Srivastava DP. $\Delta 9$-tetrahydrocannabinol and 2-AG decreases neurite outgrowth and differentially affects ERK1/2 and Akt signaling in hiPSC-derived cortical neurons. Mol Cell Neurosci. 2020;103:103463.

6. Bari M, Battista N, Pirazzi V, Maccarrone M. The manifold actions of endocannabinoids on female and male reproductive events. Front Biosci. 2011;16(498):e516.

7. Grandin T. Recommended animal handling guidelines and audit guide. A systematic approach to animal welfare. American Industry Foundation: USA. 2010

8. Kemp A., Van Heijningen A.J.K. A colorimetric micro-method for the determination of glycogen in tissues. Biochem. J. 1954;56:646-648

9. Ilavarasan R, Mallika M, Venkataraman S. Anti-inflammatory and free radical scavenging activity of Ricinus communis root extract. J Ethnopharmacol. 2006; 103(3):478-80.

10. Rao AV, Ramakrishnan S. Indirect assessment of hydroxymethylglutaryl-CoA reductase (NADPH) activity in liver tissue. Clin Chem. 1975; 21(10):1523-5.

11. Misra, HP and Fridovich I. The role of superoxide anion in the autoxidation of epinephrine and a simple assay for superoxide dismutase. J. Biol. Chem. 1972; 247(10):3170-3175

12. Jollow DJ, Mitchell JR, Zampaglione NA, Gillette JR. Bromobenzeneinduced liver necrosis. Protective role of glutathione and evidence for 3, 4-bromobenzene oxide as the hepatotoxic metabolite. Pharmacology. 1974; 11(3):151-69.

13. Aebi, H. "Catalase." Methods of enzymatic analysis. Academic press, 1974. 673-684

14. Kei S. Serum lipid peroxide in cerebrovascular disorders determined by a new colorimetric method. Clinica chimica acta. 1978;90(1):37-43.

15. Gornall AG, Bardawill CJ, David MM. Determination of serum proteins by means of the biuret reaction. J. Biol. Chem. 1949;177(2):751-66.

16. Wright, PJ, Leathwood, PD, \& Plummer, DT Enzymologia. 1972; 42: 317-327

17. Wright, PJ, Leathwood, PD, \& Plummer, DT Enzymologia. 1972;42: 317-327

18. Folch J, Lees M. and Stanley GS. A simple method for the isolation and purification of total lipides from animal tissues. J. Biol. Chem. 1957; 226(1): 497-509. 
19. Roy S, Rahaman N, Ahmed F, Metya S, Sannigrahi S. Naringenin attenuates testicular damage, germ cell death and oxidative stress in streptozotocin induced diabetic rats: naringenin prevents diabetic rat testicular damage. J. Appl. Biomed. 2013;11(3):195-208.

20. Campana A, De Agostini A, Bischof P, Tawfik E, Mastrorilli A. Evaluation of infertility. Human reproduction update. 1995;1(6):586-606.

21. Seibel MM, Zilberstein M. The diagnosis of male infertility by semen quality: the shape of sperm morphology. Hum Reprod. $1995 ; 10(2): 247$.

22. Wang Y, Wang Y, McNeil B, Harvey LM. Maca: An Andean crop with multi-pharmacological functions. Food Res Int. 2007; 40(7):783-92.

23. Cushnie TT, Hamilton VE, Lamb AJ. Assessment of the antibacterial activity of selected flavonoids and consideration of discrepancies between previous reports. Microbiol. Res. 2003 Jan 1; 158(4):281-9.

24. Gurib-Fakim A. Medicinal plants: traditions of yesterday and drugs of tomorrow. Mol. Aspects Med. 2006; 27(1):1-93.

25. Opuwari $\mathrm{C}$ and Monsees T. Green tea consumption increases sperm concentration and viability in male rats and is safe for reproductive, liver and kidney health. Scientific RepoRtS, 2020; 10(1):1-14.

26. Long J, Zhang CJ, Zhu N, Du K, Yin YF, Tan X, Liao DF and Oin, L. Lipid metabolism and carcinogenesis, cancer development. Am. J. Cancer Res. 2018; 8(5):778.

27. Luo D, Zhang M, Su X, Liu L, Zhou X, Zhang X, Zheng D, Yu C and Guan $\mathrm{Q}$. High fat diet impairs spermatogenesis by regulating glucose and lipid metabolism in Sertoli cells. Life Sciences. 2020; 257:118028.

28. Monfared AL. Correlation of Serum Lipid $P$ rofile with Histological and Seminal Parameters of Testis in The Goat. Int J Fertil Steril. 2013;7(2):122.

29. Saheed S, Oladipipo AE, Temitope BO, Bashirat YO. Aqueous extract of Cyperus esculentus L. restores and boosts sexual competence in paroxetine-dysfunctioned male Wistar rats. J. exp. integr. med. 2016; 6(1).
30. Pathak M, Sharma S, Kushwaha PP, Kumar S. Functional lead compounds and targets for the development of drugs for the treatment of male infertility. InPhytochemicals as Lead Compounds for New Drug Discovery 2020; 333-345. Elsevier.

31. Slaughter GR, Means AR. Follicle-stimulating hormone activation of glycogen phosphorylase in the Sertoli cell-enriched rat testis. Endocrinology. 1983;113(4):1476-85.

32. Rato L, Alves MG, Dias TR, Cavaco JE, Oliveira PF. Testicular metabolic reprogramming in neonatal streptozotocin-induced type 2 diabetic rats impairs glycolytic flux and promotes glycogen synthesis. J. Diabetes Res. 2015; 2015.

33. Zini A, O'Bryan MK, Magid MS, Schlegel PN. Immunohistochemical localization of endothelial nitric oxide synthase in human testis, epididymis, and vas deferens suggests a possible role for nitric oxide in spermatogenesis, sperm maturation, and programmed cell death. Biol. Reprod. 1996;55(5):935-41.

34. Peruquetti RL, Taboga SR, Oliveira MT. Expression of acid phosphatase in the seminiferous epithelium of vertebrates. Genet. Mol. Res. 2010:620-8.

35. Pandey G, Jain GC. Assessment of molybdenum induced alteration in oxidative indices, biochemical parameters and sperm quality in testis of Wistar male rats. Asian J Biochem. 2015;10(6):267-80.

36. Men S, Chen H, Chen S, Zheng S, Shen X, Wang C, Yang Z, Liu D. Effects of supplemental nitrogen application on physiological characteristics, dry matter and nitrogen accumulation of winter rapeseed (Brassica napus L.) under waterlogging stress. Sci. Rep. $2020 ; 10(1): 1-0$.

37. Nehru B, Anand P. Oxidative damage following chronic aluminium exposure in adult and pup rat brains. J. Trace Elem. Med. Biol. 2005 Dec 2; 19(2-3):203-8.

38. Lushchak VI. Glutathione homeostasis and functions: potential targets for medical interventions. Amino acids. 2012; 2012 


\section{GRAPHICAL ABSTRACT}
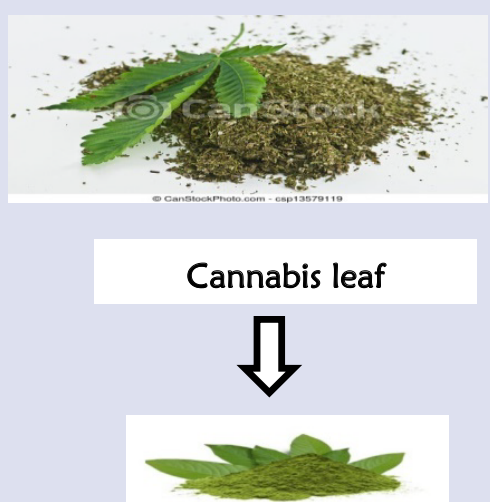

Ethanolic leaf extract of cannabis

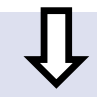

Solvent fractions of the extract

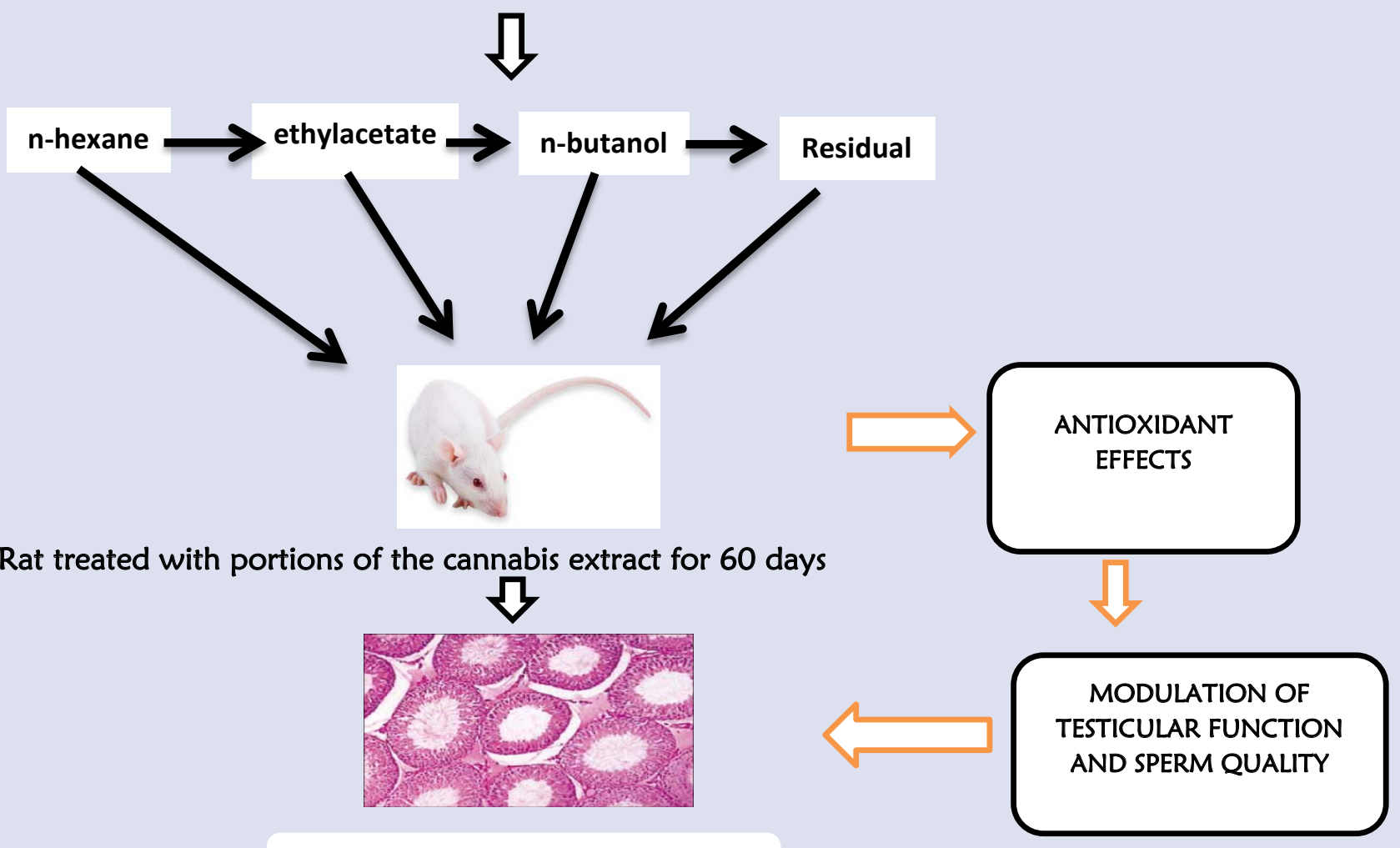

Testicular Photomicrograph of rat

Conclusion: The antioxidant activity, sperm quality and testicular functions modulation by the solvent portions of the extract was observed in this study. 


\section{ABOUT AUTHORS}
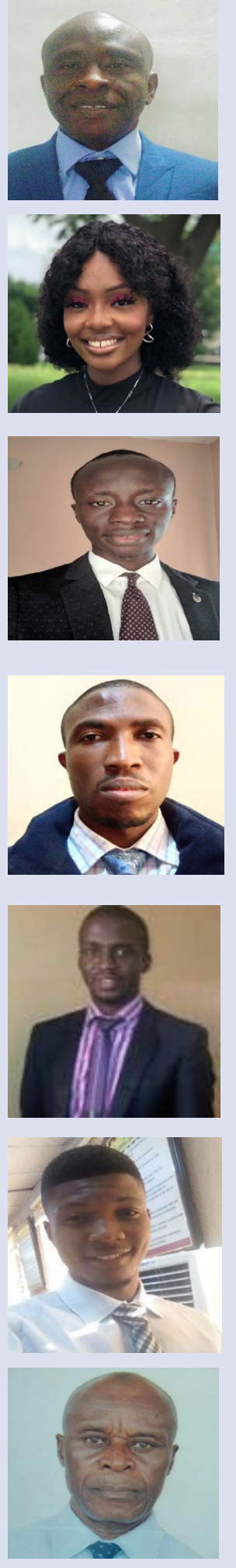

Nwonuma Charles Obiora received his Ph.D. in Biochemistry from the University of Ilorin, with a focus on Reproductive and Parasite Biochemistry. He is currently employed at the Department of Biochemistry, Landmark University Omu-Aran, Kwara State Nigeria where he is actively engaged in research and teaching. He has some publications in prestigious peer-reviewed journals to his credit.

Favours, God'slove Oluwafemi, a biochemistry graduate with a passion for research in the field of plant-based drug discovery.

Rotimi, Damilare Emmanuel is a researcher who holds a Master's degree in Biochemistry (Reproductive Biochemistry) from Landmark University, Omu-Aran, Nigeria. He is currently a Ph.D. student-cumFaculty at the Department of Biochemistry, Landmark University. His research interests and focus are in the areas of Medicinal Biochemistry, Reproductive Toxicology, and functional foods. His current research interest focuses on reproductive dysfunction by using diets such as plantain-based diet and high fat/low carbohydrate diet. He has published articles in highly reputable journals, attended several conferences and workshops. He is a member of the Nigeria Society for Experimental Biology (NISEB).

Omokolade Alejolowo holds a B.Tech. Biochemistry, FUTMINNA; M.Sc. Environmental Chemistry and Pollution Control, Ibadan. In 2015, Alejolowo began his academic/research career in the Department of Biological Sciences (now Department of Biochemistry), Landmark University Omu-Aran where he currently lectures Biochemistry courses. His research interest is in the area of environmental toxicology and phytomedicine; he has published some scientific articles published in peer-reviewed academic journals. He is a member of the Society of Experimental Biology of Nigeria (NISEB) and the Nigerian Society of Biochemistry and Molecular Biology (NSBMB).

Oluwafemi Adeleke Ojo, Ph.D., is a Lecturer at the Department of Biochemistry, College of Pure and Applied Sciences, Landmark University, Omu-Aran, Kwara state, Nigeria. His research interests and focus are in areas relating to phytomedicine, molecular toxicology, and Computational Biochemistry. He has published over 100 scientific articles in peer-review journals, two chapters in a book, and presented over 10 papers at international and national conferences. He is an editorial board member of Journal of Medicinal Plants for Economic Development in South Africa and Computational Molecular Biosciences (CMB) China. He is an academic editor for Evidence-Based Complementary and Alternative Medicine.

Afolabi Boluwatife Lawrence is a pharmacogenomics-scientist who received his B.Tech (Biochemistry) from Federal University of Technology Minna, Nigeria, in 2018 before undertaking graduate training at Landmark University in Medicinal Biochemistry in 2019. He then got an EDCTP2 scholarship to study Genomics and Precision Medicine under the mentorship of Professor Collen Masimirembwa in 2020. His long-term research goal is to better understand the cancer genome for the delivery of more effective and personalized chemotherapies. He is currently exploiting sex differences in cancer for better-personalized treatment and survival.

Irokanulo, Emenike Onyebum,

Holds a Ph.D. in Applied Microbiology from the University of Jos, Nigeria. A Fellow of the Medical Laboratory Science Council of Nigeria (FMLSCN). A biomedical scientist with training in vaccine development, formulation, and production. Presently a Faculty in the Department of Microbiology, Landmark University, Omu-Aran, Nigeria.

Cite this article: Nwonuma CO, Favours GO, Rotimi DE, Alejolowo OO, Ojo OA,Afolabi BL, et al. Comparative Modulatory Assessment of the Sperm Quality and TesticularFunction by Solvent Fractions of the Cannabis Extract in Rats. Pharmacogn J. $2021 ; 13(6)$ Suppl: 1678-1687. 